\title{
SYUKUR SEBAGAI SEBUAH PEMAKNAAN
}

\author{
Handrix Chris Haryanto ${ }^{1}$, Fatchiah E. Kertamuda ${ }^{2}$ \\ ${ }^{12}$ Departement of Psychology of Paramadina University \\ ${ }^{1}$ handrix.haryanto@paramadina.ac.id \\ 2fatchiah.kertamuda@paramadina.ac.id
}

\begin{abstract}
Abstrak
Penelitian ini bertujuan untuk melakukan studi mengenai konsep syukur dan dilakukan pada kalangan mahasiswa di Universitas Paramadina. Pertanyaan penelitian yang dibangun berupa bagaimanakah gambaran konsep syukur yang maknai oleh para responden. Penelitian ini menggunakan metode kualitatif analisis isi dengan menggunakan pertanyaan terbuka dan dianalisis dengan analisis isi secara induktif. Subjek dalam penelitian ini adalah mahasiswa di universitas Paramadina yang berjumlah 192 orang. Hasil penelitian ini menunjukkan bahwa konsep rasa syukur dibangun atas 5 kategori yang terkait dengan kondisi menerima $(41,15 \%)$, berterimakasih $(23,44 \%)$, menikmati (9,38\%), menghargai (6,25\%), dan memanfaatkan (6,25\%). Kelima kategori tersebut mengarahkan pada kondisi yang ada dan dimiliki dalam diri serta segala proses kehidupan yang dijalani. Di dalam penelitian ini, objek rasa syukur ini diarahkan pada keberadaan Tuhan. Hasil dalam penelitian ini memberikan gambaran yang berbeda terkait dengan konsep syukur yang biasanya menjadi rujukan dalam penelitian di barat khususnya terkait dengan objek keberadaan Tuhan.
\end{abstract}

Kata Kunci: syukur, menerima, berterimakasih, menikmati, menghargai, memanfaatkan.

\section{GRATITUDE AS A MEANING}

\author{
Handrix Chris Haryanto ${ }^{1}$, Fatchiah E. Kertamuda ${ }^{2}$ \\ ${ }^{12}$ Departement of Psychology of Paramadina University \\ ${ }^{1}$ handrix.haryanto@paramadina.ac.id, ${ }^{2}$ fatchiah.kertamuda@paramadina.ac.id
}

\begin{abstract}
This research aims to study about gratitude concept in students of Paramadina University. The research question is how description about gratitude concept which is interpreted by respondents. This research used qualitative content analysis with open-ended questionnaire and analysis with inductive content analysis. Respondents in this research are 192 students at Paramadina University. The results showed that gratitude concept built with five categories that is acceptance (41.15\%), gratefulness (23.44\%), enjoy (9.38\%), appreciate $(6.25 \%)$, andutilize $(6.25 \%)$. Thisfivecategoriesdirectingto therealconditionandownedinsideof self and all the life lived. The result of this research also directing to the existence of God. This result shows the difference view with the west literature, especially related to the object of God.
\end{abstract}

Keywords: gratitude, acceptance, gratefulness, appreciate, utilize. 


\section{PENDAHULUAN}

Dalam konteks literatur psikologi kontemporer konsep syukur menjadi salah satu bagian pembahasan dalam kajian psikologi positif yang mengacu pada konsep psikologi barat. Syukur sebagai konsep di Indonesia seringkali di dalam kajian psikologi positif sejalan dengan konsep gratitude yang dikembangkan di psikologi barat. Konsep syukur dalam perkembangannya sudah memiliki sejarah yang panjang. Emmons (2004) menjelaskan bahwa konsep tersebut dalam seabad ini telah lama menjadi kajian para kalangan teolog, filusuf moral, maupun para penulis yang menggambarkan sebagai bagian suatu kebajikan serta suatu karakter yang unggul. Dalam konteks budaya pun, konsep syukur sudah memiliki konsep-konsep yang sejalan dengan nilai-nilai yang dimiliki dalam budaya tersebut. Meskipun telah menjadi kajian yang lama pada kalangan-kalangan tersebut, dalam konteks psikologi konsep syukurmasih memiliki sejarah kajian yang cukup pendek.

Pada kajian psikologi lebih jauh, konsep gratitude telah banyak dikonsepkan oleh para ahli. Emmons (2004) lebih jauh menjelaskan bahwa konsep syukur ini berasal dari kata gratia yang memiliki arti menyukai atau kata gratus yang memiliki arti menyenangkan.Menurut Park, Peterson\& Seligman (2004) gratitude digambarkan dengan kondisi individu yang sadar dan berterimakasih atas segala hal baik yang terjadi. Individu dalam hal ini dituntut juga untuk bisa mengekspresikan maupun mengungkapkan rasa terimakasih. Syukur dalam hal ini merupakan bentuk emosi yang menyenangkan dengan didahului terbentuknya suatu persepsi bahwa dirinya mendapatkan suatu manfaat dari pemberian orang lain dan didasarkan pada setelah menerima manfaat dari agen sosial (McCullough, Kimeldorf, \& Cohen, 2008). Dalam kajian yang lain, gratitude diungkapkan sebagai bentuk perasaan yang dialami oleh individu ketika menerima suatu kebaikan atau keuntungan dari seorang penderma (Lambert, Graham \&Fincham, 2009).Emmons, McCullough and Tsang (2003) menjelaskan konsep syukur sebagai bentuk perasaan takjub, berterimakasih dan menghargai atas manfaat yang diperolehnya. Perasaan tersebut bisa diarahkan pada orang lain maupun pada diri sendiri. Selain halnya konteks yang sudah dijelaskan sebelumnya, konsep gratitude menurut McCullough,TsangandEmmons (2004) sangat terkait dengan konteks kepribadian, emosi, kehidupan sosial dan kesejahteraan psikologis. Fitzgerald (Emmons, 2004) menambahkan bahwa dalam konsep gratitudeterdiri dari tiga komponen yaitu berupa bentuk apresiasi yang hangat terhadap sesuatu atau seseorang, niat baik terhadap sesuatu atau seseorang dan keberadaan perilaku yang merupakan implikasi dari apresiasi dan niat tersebut.

Melihat lebih jauh terkait penelitiandengan variabel gratitude saat ini tidak terlepas dari konstruk thankfulness, gratefulness, dan appreciative yang tergambar dalam skala Gratitude GQ-6 (McCullough, Emmons, \& Tsang, 2002). Thankfulnessdan gratefulness dalam konsep gratitude dijelaskan oleh Steindl-Rast (2004) mengarahkan pada 
dua kondisi yang bersifat personal dan transpersonal. Thankfulness dianggap sebagai bentuk personal gratitude yang mana dalam konsep ini terdapat ekspresi maupun ungkapan terimakasih terhadap seseorang yang memberikan manfaat atau kebaikan bagi dirinya. Konsep thankfullness ini secara alaminya relasinya bersifat sosial. Lain halnya gratefulness yang dianggap sebagai bentuk transpersonal gratitude karena tidak hanya menekankan pada bentuk ekspresi maupun ungkapan terimakasih yang terlihat,akan tetapi mengarahkan pada kondisi kesadaran dalam diri yang lebih mendalam terkait dengan pengalaman yang dialaminya. Dalam konteks gratefulness individu tidak harus dihadapkan dengan sosok atau objek yang jelas untuk memunculkan rasa terimakasih tersebut. Lebih jauh dijelaskan bahwa jika dikaitkan dalam konteks agama dan spiritual, keberadaan Tuhan, takdir maupun kekuatan-kekuatan alam menjadi sosok terpenting sebagai faktor munculnya pengalaman akan rasa syukur ini. Untuk konsep appreciative itu sendiri mengarahkan pada kondisi emosi yang bersifat positif dalam diri seseorang (McCraty \& Childre, 2004). McCraty and Childe (2004) menjelaskan lebih lanjut bahwa konsep ini pada umumnya dipahami individu sebagai bentuk respon terhadap orang lain atas apa yang dilakukannya. Padahal keberadaan konsep appreciative ini juga dapat diarahkan pada diri sendiri atas apa yang telah dilakukan maupun diselesaikan. Konsep appreciative ini lebih mudah dipahami sebagai bentuk perasaan positif dalam diri yang bersifat aktif dan diantaranya dapat mengarahkan individu untuk memunculkan satu ekspresi maupun ungkapan terimakasih (thankfulness) sebagai ungkapan rasa syukur.

Selain konstruk syukur yang mendasarkan pada skala Gratitude GQ-6, penelitian konsep syukur yang ada juga mengacu pada skala Gratitude, Resentment and Appreciation Test (GRAT). Skala GRAT ini mulai dikenal salah satunya melalui penelitian yang dilakukan oleh Watkins, Woodward, Stone and Kolts (2003). Dalam skala GRAT ini, konsep syukur dijelaskan dalam 3 dimensi yaitu sense of abundance, appreciation of simple pleasure dan appreciation of others. Watkins (2014) menjelaskan lebih lanjut bahwa 3 dimensi tersebut merupakan pilar maupun karakteristik orang-orang yang bersyukur. Sense of abundancemengarahkan pada kondisi individu yang merasakan bahwa hidupnya selalu melimpah dan diberikan anugerah. Individu tidak merasa kekurangan satu apapun. Individu juga merasakan bahwa dirinya telah menerima lebih dari apa yang berhak diterimanya. Appreciation of simple pleasure merupakan bentuk penghargaan dalam diri terkait dengan pengalaman-pengalaman maupun hal-hal yang telah dilakukan walaupun sifatnya sangat sederhana. Appreciation of others mengarahkan bentuk penghargaan individu terhadap individu lain sebagai bentuk respon terhadap kontribusi yang sudah diberikan orang lain tersebut. Selain itu, individu yang bersyukur harus menyadari bahwa memberikan apresiasi merupakan hal yang penting.

Meskipun konsep syukur sudah dianggap memiliki konstruk yang baik dengan 
beberapa skala yang ada, menjadi catatan lebih lanjut mengenaikonsep syukur adalahketerkaitannya dengan keberadaan konteks budaya, agama maupun filosofis(Emmons, 2004). Konsep syukur dalam hal ini bisa saja memiliki penekanan maupun konstruk yang berbeda ketika dihadapkan dengan konteks budaya, agama maupun filosofi yang berbeda pula. Hal tersebut dapat diartikan bahwa konstruk konsep syukur yang terbentuk dalam individu tidak dapat dilepaskan dari proses pembelajaran yang mengarahkan pada satu nilai sangat erat dengan nilai budaya, agama maupun filosofi yang ada di sekitarnya. Kondisi proses pembelajaran nilai-nilai seperti halnya tersebut sering dipahami sebagai bentuk proses sosialisasi dan enkulturasi. Menurut Matsumoto dan Juang (2003) sosialisasi merupakan suatu proses individu di dalam melakukan pembelajaran dan internalisasi mengenai suatu aturan maupun ketentuan dalam berperilaku yang dipengaruhi oleh budaya. Enkulturasi dalam hal ini merupakan produk dari proses sosialisasi. Berdasarkan pada pemahaman tersebut, maka peneliti tertarik untuk melihat lebih jauh bagaimanakah konsep syukur yang dipahami oleh responden yang memiliki kultur yang berbeda dalam hal ini adalah responden di Indonesia.

\section{METODE}

\section{Sampel}

Sampel dalam penelitian ini adalah mahasiswa Universitas Paramadina dengan total mahasiswa sebanyak 192 orang (68 laki- laki dan 124 perempuan)dengan rentang usia antara 17-24 tahun.

\section{Metode penelitian}

Penelitian ini menggunakan metode kualitatif analysis isi. Metode penelitian kualitatif analisis isi menurut Hsieh and Shannon(2005) merupakan salah satu bentuk metode dalam penelitian kualitatif yang mengarahkan pada upaya peneliti untuk mencari sebuah makna dari data-data yang sifatnya tekstual. Upaya untuk mencari makna ini dilakukan dengan melalui proses pengkodingan yang sistematis.Metode penelitian kualitatif analisis isi sejalan dengan pendekatan grounded theory (Sandelowski \& Barosso, 2003) yang mengarahkan pada upaya peneliti untuk mencoba memahami fenomena dan mengembangkan sebuah konsep yang bersifat induktif (tidak membuktikan teori) dan bottom up (Glasser \& Strauss, 1967).

\section{Alat pengumpul data dan analisis data}

Penelitian ini menggunakan kuisioner terbuka sebagai alat pengumpul data. Kuisioner terbuka merupakan salah satu alat pengumpul data yang dapat digunakan dalam penelitian kualitatif analisis isi (Hancock, Okleford, \& Windridge, 2009). Pertanyaan penelitian yang dibangun dalam penelitian ini adalah "Apa makna syukur pada mahasiswa Paramadina?". Data yang diperoleh denganpertanyaan terbuka dianalisis menggunakan analisis konten (Weber, 1990). Analisis konten yang digunakan adalah analisis yang bersifat induktif yang bertujuan untuk membangun suatu konsep maupun dinamika berdasar pada jawaban 
responden bukan untuk melakukan verifikasi terhadap salah satu konsep teori (Ello \& Kyngas, 2008).

\section{Validitas dan reliabilitas penelitian}

Dalam upaya mencapai validitas dan reliabilitas dalam penelitian, maka peneliti telah melakukan beberapa metode yaitu peer debriefing dan intercoder agreement menurut Creswell (2009). Dalam pelaksanaan peer debriefing ini telah dilakukan review oleh rekan sejawat dosen terkait dengan hasil penelitian yang dihasilkan. Untuk intercoder agreement dalam hal ini antar peneliti telah melakukan proses pemeriksaan kembali hasil penelitian dan memperoleh kesepakatan bersama terhasil hasil tema yang diperoleh dalam penelitian.

\section{HASIL DAN PEMBAHASAN}

Gambar 1. Persentase Kategori Makna Syukur

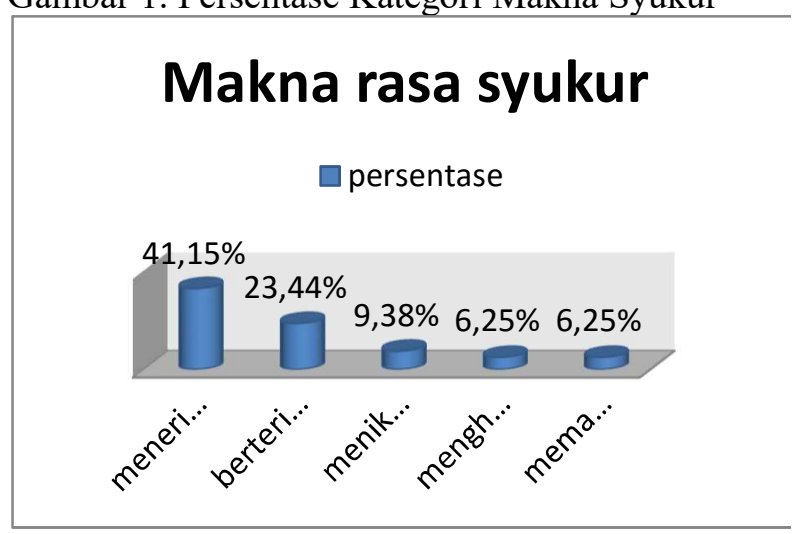

Pada gambar 1 menunjukkan bahwa makna rasa syukur bagi mahasiswa di Universitas Paramadina terbangun atas 5 kategori yaitu menerima (41.15\%), berterimakasih (23.44\%), menikmati (9.38\%), menghargai $(6.25 \%)$ dan memanfaatkan (6.25\%). Untuk kategori terakhir sebanyak $13.53 \%$ berupa kategori others. Kategori others merupakan kategori yang dibangun atas subkategori yang terdiri dari jawaban peneliti anggap tidak relevan dan jawab yang kosong atau tidak diisi oleh para responden penelitian.

Gambar 2. Paparan Makna Konsep Syukur

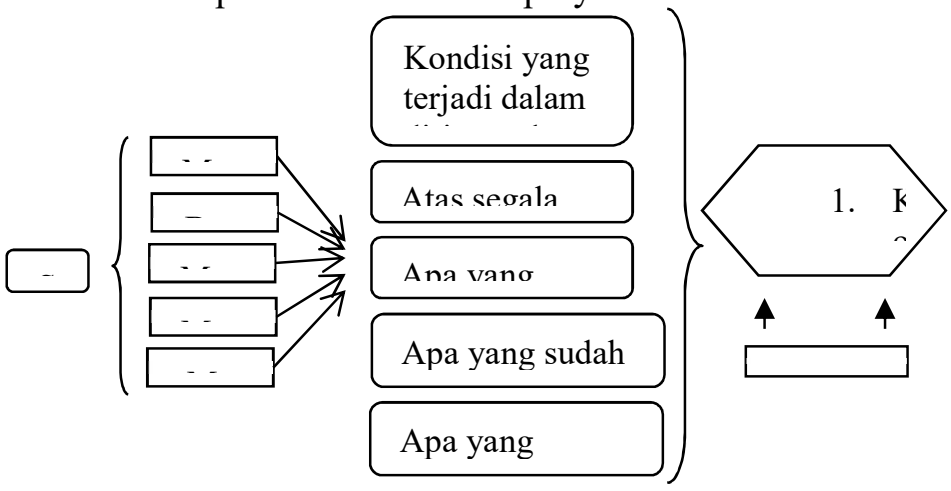

Pada gambar 2. merupakan gambaran mengenai dinamika dalam konsep syukur yaitu berupa respon yang dipahami (menerima, berterimakasih, menikmati, menghargai, dan memanfaatkan) serta objek dari respon yang dipahami oleh responden.

Berdasarkan pada gambar 2. dapat disimpulkan bahwa makna syukur terdiri dari bentuk penerimaan, berterimakasih, menikmati, menghargai dan memanfaatkan atas segala sesuatu yang dimiliki saat ini maupun proses kehidupan yang sedang dijalani. Penekanan akanlima pemaknaan rasa syukur tersebut diarahkan pada apa yang dimiliki serta proses kehidupan yang dijalani saat ini yang dipahami sebagai pemberian Tuhan.

Makna konsep syukur dalam penelitian ini mengarahkan pada lima kategori berupa bentuk penerimaan, berterimakasih, menikmati, menghargai dan memanfaatkan. Kelima kategori tersebut erat pada objek segala sesuatu yang dimiliki serta proses kehidupan yang sedang dijalan dengan menekankan pada keberadaan Tuhan. Pada pemaknaan akan penerimaan dalam penelitian syukur dalam 
literatur psikologi barat menurut Putra (2014) kurang begitu banyak ditemui.

Konsep penerimaan yang terkait dengan Tuhan ini lebih banyak ditemui pada ranah religiusitas maupun spiritualitas (Gall, et. al, 2005). Konsep penerimaan ini menurut Gall, et. al. (2005) mengarahkan pada hubungannya dan keterlibatan dengan Tuhan sehingga menjadikan individu terhindar dari perasaan yang menekan dalam dirinya ketika dihadapkan dengan situasi yang tidak menyenangkan. Menjelaskan lebih jauh dalam kaitannya dengan keberadaan Tuhan, Al-Jawziyyah (alKhattab, 1997) sendiri juga memberikan gambaran konsep penerimaan dalam rasa syukur ini mengarahkan pada konsep sabar dalam agama Islam. Hal tersebut dijelaskan sebagai penerimaan pada ketetapan Allah sebagai Tuhan yang menjadikan individu harus mampu menerima apapun yang diberikan oleh Allah baik yang bersifat tidak menyenangkan maupun sebaliknya. Penekanan pada konteks religiusitas dan spiritual terkait dengan kategori penerimaan dapat terlihat dalam jawaban para responden yaitu "menerima apapun yang diberikan oleh Tuhan".

Pada pemaknaan akan berterimakasih dalam penelitian syukur ini dapat dikatakan sejalan dengan konsep gratefulness yang menekankan pada konsep transedental. Konsep transedental ini mengarahkan kembali salah satunya pada keberadaan Tuhan jika dikembalikan dalam konteks agama (SteindlRast, 2004). Meskipun konsep gratefulness inibersifat transedental, akan tetapi jika ditelaah lebih lanjut dapat diketahui bahwa terdapat perbedaan konsep gratefulness dalam literatur barat dan hasil penelitian yang ada. Perbedaan ini dapat dikaji dalam sisi konsep yang menjelaskan bahwa ucapan terimakasih ini tidak perlu mendapati sosok yang jelas sebagai objek akan tetapi lebih menekankan pada kondisi kesadaran dalam diri (Steindl-Rast, 2004). Emmons and Kneezel (2005) dalam studinya juga menjelaskan bahwa konsep syukur dalam perspektif ilmu sosial lebih mengarahkan pada hubungan resiprokal (timbal balik) antar personal.

Dalam hal ini dijelaskan bahwa ketika individu menerima sesuatu maka memiliki kewajiban untuk memberikan kembali sebagai bentuk timbal balik. Dalam penelitian ini secara lebih khusus mengarahkan makna syukur sebagai bentuk ucapan terimakasih kepada Tuhan. Penekanan pada konteks keberadaan Tuhan dapat terlihat dalam jawaban responden yaitu 'berterimakasih kepada Tuhan atas segala sesuatu yang terjadi dalam hidup".

Pada pemaknaan akan menikmati dalam penelitian syukur ini sejalan dengan konsep yang dijelaskan oleh Emmons and Mishra (2012). Emmons and Mishra (2012) menjelaskan bahwa konsep syukur pada implementasinya akan mengarahkan kondisi yang positif bagi individu salah satunya terkait dengan proses menikmati hidup. Konteks syukur ini menjadikan individu mampu menikmati hidup yang merupakan hasil kemampuan individu untuk melihat hal-hal positif dari proses kehidupan yang dijalaninya. Individu yang bersyukur dalam hal ini tidak lagi memfokuskan pada hal yang bersifat materialism yang dapat mengarahkan individu 
pada ketidakpuasan dalam hidup (Lambert, Fincham, Stillman, \& Dean, 2009).

Selain itu, keberadaan syukur juga dapat menjadikan individu merasakan bentuk emosi positif salah satunya adalah kebahagiaan (Watkins, Woodward, Stone, Kolts, 2003; Safaria, 2014). Perbedaan makna menikmati dalam literatur barat dengan penelitian ini adalah adanya penekanan pada keberadaan Tuhan sebagai sosok sentral yang diyakini sebagai pihak yang memiliki kekuasaan atas segala kondisi maupun proses kehidupan yang dijalani. Hal ini dapat terlihat dalam jawaban responden yaitu "menerima semua yang telah diberikan oleh Tuhan".

Pada pemaknaan menghargai dalam penelitian ini jika dibahas lebih mendalam, maka akan didapati perbedaan-perbedaan dengan literatur barat. Dalam literatur barat, konsep menghargai dapat disejajarkan dengan konsep appreciate. Penggambaran konsep appreciate dalam konsep barat diantaranya menurut McCraty and Childre (2004) menekankan pada konteks bentuk penghargaan yang diarahkan pada orang lain maupun pada diri sendiri. Bentuk penghargaan yang diarahkan kepada orang lain ini merupakan bentuk respon terhadap aksi orang tersebut. Respon penghargaan ini tidak selalu diarahkan hanya pada aksi-aksi yang bersifat positif atau memberikan manfaat bagi diri sendiri. Untuk penghargaan terhadap diri sendiri dapat digambarkan dalam bentuk menghargai diri sendiri atas pekerjaan yang sudah diselesaikan, adanya kemajuan dari upaya pencapaian tujuan atau usaha-usaha positif yang dilakukan untuk membuat perubahan dalam diri. Meskipun
Emmons, McCullough and Tsang (2003) menjelaskan bahwa keberadaan apresiasi ini ada yang bersifat transsendental yang mengarahkan pada keberadaan Tuhan, alam maupun kosmos, akan tetapi dalam pemaparannya secara keseluruhan Emmons, et. al (2003) lebih banyak membahas apresiasi dalam konteks interpersonal. Penekanan pada keberadaan Tuhan sebagai pusat dalam pemaknaan menghargai ini dapat terlihat dari jawaban responden yaitu "menghargai hidup yang diberikan oleh Tuhan".

Pada pemaknaan memanfaatkan dalam penelitian syukur ini mengarahkan pada upaya individu untuk bisa memanfaatkan apa yang dimiliki dan proses kehidupan yang dijalani untuk hal-hal yang bersifat positif. Makna memanfaatkan pada dasarnya bisa disejajarkan dengan konsep moral reinforcer yang mengarahkan pada upaya individu dalam mengekspresikan rasa syukur tersebut dalam bentuk kata-kata maupun tindakan (McCullough \& Tsang, 2004). McAdams andBauer (2004) menjelaskan lebih lanjut bahwa moral reinforcer merupakan sebuah bentuk reward sosial dan terus mendorong munculnya tindakan moral dalam komunitas sosial.

Beberapa perilaku yang berdasar pada moral ini digambarkan dengan beberapa hal diantaranya berupa perilaku prososial (Emmons, McCullough, \& Tsang, 2003) ,maupun perilaku-perilaku kebajikan yang bisa berupa empati, simpati, maupun mampu mengoreksi kesalahan dalam diri sendiri yang bisa berakibat buruk pada ranah sosial (McCullough, Kilpatrick, Emmons, \& Larson, 
2001). Pemaknaan pemanfaatan terkait dengan rasa syukur dalam penelitian ini kembali lagi diarahkan pada keberadaan Tuhan sebagai pihak yang memberikan segala sesuatu maupun kondisi hidup yang sedang dijalani. Individu dituntut untuk bisa memanfaatkan apa yang sudah diberikan oleh Tuhan dengan melakukan perilaku-perilaku yang bersifat positif sebagai bentuk rasa syukur itu sendiri. Penekanan akan pemaknaan memanfaatkan yang didasarkan akan keberadaan Tuhan dapat terlihat dari jawaban responden yaitu "menggunakan apa yang diberikan oleh Tuhan dengan baik”.

\section{KESIMPULAN}

Berdasarkan pada pembahasan yang sudah dipaparkan di atas maka dapat disimpulkan bahwa penelitian mengenai makna syukur ini menekankan pada keberadaan Tuhan sebagai motif di dalam memunculkan reaksi terkait dengan keberadaan syukur itu sendiri. Dalam penelitian ini juga memberikan gambaran yang cukup mendasar mengenai konsep syukur yang ada pada literature barat. Perbedaan yang cukup mencolok ini berupa penekanan akan keberadaan Tuhan sebagai pihak yang penting dalam memaknai rasa syukur dalam penelitian ini. Relasi transcendental menjadi poin penting dan utama dalam memaknai rasa syukur ini sendiri. Dalam literatur barat sendiri, konsep syukur lebih banyak diarahkan pada kondisi relasi interpersonal antar individu. Pembahasan mengenai konsep syukur yang diarahkan pada relasi transsendental belum menjadi fokus pembahasan dan seringkali dijelaskan sebagai pembahasan di ranah agama.

\section{DAFTAR PUSTAKA}

Al-Khattab, N. (1997). Patience and gratitude by Ibn Qayyim al-Jawziyyah. http://www.missionislam.com/knowledg e/books/Patience_and_Gratitude.pdf diunduh pada $12 \overline{\text { Juni }} 2015$.

Bono, G. \& McCullough M. E. (2006). Positive responses to benefit and harm: Bringing forgiveness and gratitude into cognitive psychotherapy. Journal of Cognitive Psychotherapy, 20, 147-158.

Creswell, J. W. (2009). Research design: Qualitative, quantitative, and mixed methods approaches $3^{\text {rd }}$ ed. California: Sage Publications.

Elo, S.\& Kyngäs, H. (2008). The qualitative content analysis process. Journal of Advanced Nursing, 62 (1), pp. 107-115.

Emmons, R. A. (2004). The psychology of gratitude: An introduction. In Emmons, R. A., \& McCullough, M. E. (Eds).The Psychology of Gratitude. New York: Oxford University Press.

Emmons, R. A., \& Kneezel, T. T. (2005). Giving thanks: Spiritual and religious correlates gratitude. Journal of Psychology and Christianity, 24(2), 140148.

Emmons, R. A., \& McCullough, M. E. (2003). Counting blessings versus burdens: An experimental investigation of gratitude and subjective well-being in daily life. Journal of Personality and Social Psychology, 84, 377-389.

Emmons, R. A., McCullough, M. E. \& Tsang, J-A. (2003). The assessment of gratitude. In Lopez, S. J. \& Snyder, C. R. (Eds) Positive psychological assessment: A handbook of models and measures. United States of America: American Psychological Association.

Emmons, R. A., \& Mishra, A. (2012). Why gratitude enhances well-being: What we know, what we need to know. In Sheldon, K., Kashdan, T., \& Steger, M.F. (Eds.) Designing the future of positive 
psychology: Taking stock and moving forward. New York: Oxford University Press.

Gall, T. L., Charbonneau, C., Clarke, N. H., Grant, K., Joseph, A., \& Shouldice, L. (2005). Understanding the nature and role of spirituality in relation to coping and health: Conceptual framework. Canadian Psychology.46, 88-104.

Glasser, B. G., \& Strauss, A. L. (1967). The discovery of grounded theory: Strategies for qualitative research. New Brunswick: Aldine Transaction.

Hancock, B., Ockleford, E., \& Windridge, K. (2009). An introduction to qualitative research. http://www.rdsyh.nihr.ac.uk/wpcontent/uploads/2013/05/5 Introduction -to-qualitative-research-2009.pdf diunduh pada 12 Agustus 2015.

Hsieh, H-F., \& Shannon, S. E. (2005). Three approaches to qualitative content analysis. Qualitative Health Research, 15(9), 1277-1288.

Lambert, N. M., Fincham, F. D., Stillman, T. F., \& Dean, L. R. (2009). More gratitude, less materialism: The mediating role of life satisfaction. The Journal of Positive Psyhcology, 4(1), 32-42.

Lambert, N. M., Graham, S. M., Fincham, F. D. (2009). A prototype analysis of gratitude: Varieties of gratitude experiences. Personality and Social Psychology Bulletin, 35(9), 1193-1207.

Matsumoto, D., \& Juang. (2003), L. Culture and Psychology (3rd ed.) New York: Wadsworth.

McAdams, D. P. \& Bauer, J. J. (2004). Gratitude in modern life: Its manifestations and development. In Emmons, R. A., \& McCullough, M. E. (Eds) The Psychology of Gratitude. New York: Oxford University Press.

McCraty, R., \& Childre, D. (2004). The gratefull heart: The psychophysiology of appreciation. In Emmons, R. A., \& McCullough, M. E. (Eds) The
Psychology of Gratitude. New York: Oxford University Press.

McCullough, M. E.,Emmons, R. A., \&Tsang, JA. (2002). The grateful disposition: A conceptual and empirical topography. Journal of Personality and Social Psychology, 82(1), 112-127.

McCullough, M. E., Kilpatrick, S. D., Emmons, R. A., \& Larson, D. B. (2001). Is gratitude a moral affect.Psychological Bulletin, 127(2), 249-266.

McCullough, M. E., Kimeldorf, M. B., \& Cohen, A. D. (2008). An adaptation for altruism? The social causes, social effects, and social evolution of gratitude. Current Directions in Psychological Science, 17, 281-284

McCullouh, M. E. \& Tsang, J-A. (2004). Parents of the virtues? The prosocial contours of gratitude. In Emmons, R. A., \& McCullough, M. E. (Eds) The Psychology of Gratitude. New York: Oxford University Press.

McCullough, M. E., Tsang, J-A., \& Emmons, R. A. (2004). Gratitude in intermediate affective terrain: Links of grateful moods to individual differences and daily emotional experience. Journal of Personality and Social Psychology, 86, 295-309.

Park, N., Peterson, C., \& Seligman, M. E. P. (2004). Strengths of character and wellbeing. Journal of Social and Clinical Psychology, 23(5), 603-619.

Putra, J. S. (2014). Syukur: Sebuah konsep indigenous psikologi Islami. Jurnal Soul, $7(2), 35-44$.

Polak, E., \& McCullough, M. E. (2006). Is gratitude an alternative to materialism?.Journal of Happiness Studies, 7, 343-360.

Safaria, T. (2014). Forgiveness, gratitude, and happiness among college students. International Journal of Public Health Science, 3 (4), 241-245.

Sandelowski, M., \& Barroso, J. (2003). Classifying the findings in qualitative 
studies. Qualitative Health Research, 13(7), 905-923.

Steindl-Rast, D. (2004). Gratitude as thankfulness and as gratefulness. In Emmons, R. A., \& McCullough, M. E. (Eds).The Psychology of Gratitude. New York: Oxford University Press.

Watkins, P. C. (2014). Gratitude and the good life: Toward a psychology of appreciation. Dordrecht: Springer.

Watkins, P. C., Woodward, K., Stone, T., \& Kolts, R. L. (2003). Gratitude and happiness: Development of a measure of gratitude, and relationships with subjective well-being. Social Behavior and Personality, 31(5), 431-452.

Weber, R. P. (1990). Basic Content Analysis (second edition)-Series Quantitative Applications in the Social Sciences. SAGE Publication: USA. 